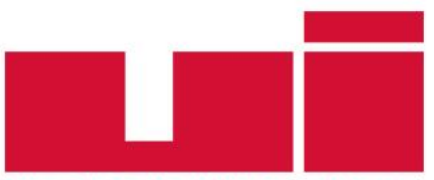

ULLUSLARARASIILIȘKiLER

Akademik Dergi

Yayın ilkeleri, izinler ve abonelik hakkında ayrıntılı bilgi:

E-mail: bilgi@uidergisi.com.tr

Web: www.uidergisi.com.tr

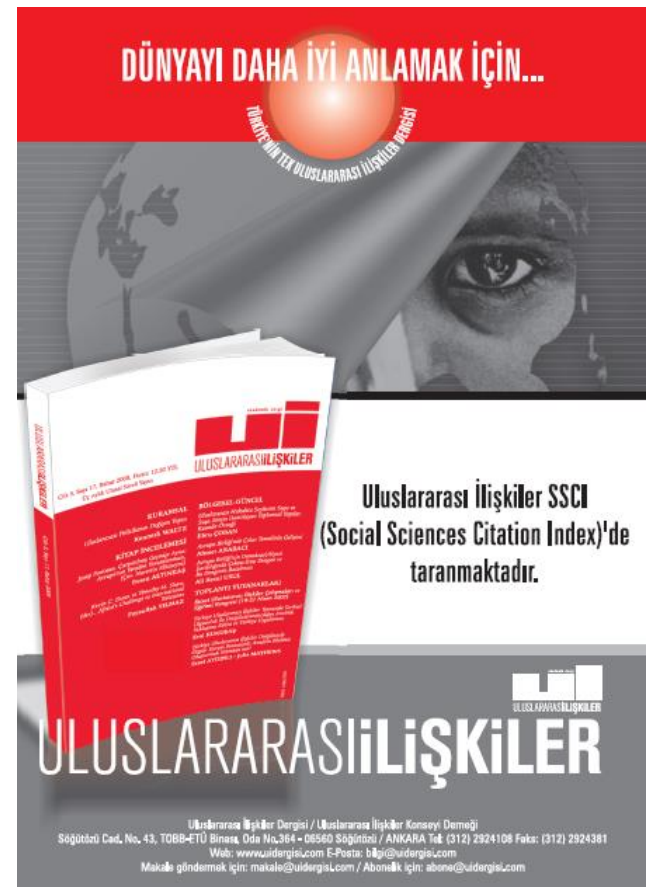

\title{
Avrupa Birliği Üyesi Ülkelerde ve Türkiye'de Düşük Karbonlu ve İklime Dirençli Bir Topluma Geçiş: Ampirik Bir Analiz
}

\author{
Hayriye ATIK* \\ * Prof. Dr., İktisat Bölümü, Erciyes Üniversitesi
}

Bu makaleye atıf icin: Atik, Hayriye, “ Avrupa Birliği Üyesi Ülkelerde ve Türkiye'de Düşük Karbonlu ve İklime Dirençli Bir Topluma Geçiş: Ampirik Bir Analiz", Uluslararası İlişkiler, Cilt 14, Sayı 54, 2017, s. $127-147$.

Bu makalenin tüm hakları Uluslararası İlişkiler Konseyi Derneği'ne aittir. Önceden yazılı izin alınmadan hiç bir iletişim, kopyalama ya da yayın sistemi kullanılarak yeniden yayımlanamaz, çoğaltılamaz, dağıtılamaz, satılamaz veya herhangi bir şekilde kamunun ücretli/ücretsiz kullanımına sunulamaz. Akademik ve haber amaçlı kısa alıntılar bu kuralın dışındadır.

Aksi belirtilmediği sürece Uluslararası Illişkiler'de yayınlanan yazılarda belirtilen fikirler yalnızca yazarına/yazarlarına aittir. UİK Derneğini, editörleri ve diğer yazarları bağlamaz. 


\title{
Avrupa Birliği Üyesi Ülkelerde ve Türkiye'de Düşük Karbonlu ve İklime Dirençli Bir Topluma Geçiş: Ampirik Bir Analiz
}

\author{
Hayriye ATÍK \\ Prof. Dr., Erciyes Üniversitesi, İktisat Bölümü, İktisadi ve İdari Bilimler Fakültesi, Kayseri. \\ E-Posta: atik@erciyes.edu.tr
}

\section{ÖZET}

Ülkelerin iklim değişikliği performansları genellikle iklim değişikliği ve düşük karbon ekonomisi endeksleri adı verilen, çeşitli göstergelere ait rakamlardan oluşan seriler ile ölçülmektedir. Endekslerle karşılaştırıldığında daha fazla göstergenin kullanıldığı bu makalede, amaç, Avrupa Birliği (AB) üyesi ülkelerin ve Türkiye'nin iklime dirençli düşük karbonlu bir ekonomiye geçişte göreli başarı düzeylerini belirlemektir. İklime dirençli bir ekonomiden kastedilen, iklim değişikliğinin negatif etkilerine adapte olmuş bir ekonomidir. Düşük karbonlu bir ekonomi ise, sera gazı salınımlarını azaltmış bir ekonomidir. Kümeleme ve ayırma analizleri kullanılarak yapılan ampirik analizlerde, AB tarafından yayınlanan 23 iklim değişikliği göstergesine ait 2014 yılı verileri kullanılmıştır. Bulgular, analize dahil edilen 29 ülkenin, düşük karbon ekonomisi göstergeleri bakımından 10 farklı gelişme düzeyi sergilediklerini ortaya koymuştur. Türkiye, hiçbir AB üyesi ile aynı grupta yer almamış, tek başına bir küme oluşturmuştur. Ayırma analizi sonuçları, Türkiye'nin oluşturduğu kümenin diğerlerinden en uzak küme olduğunu göstermiştir.

Anahtar Kelimeler: İklim değişikliği göstergeleri, iklim değişikliği endeksi, düşük karbon ekonomisi endeksi, kümeleme analizi, ayırma analizi.

\section{The Transition Towards A Low Carbon and Climate Resilient Society within the European Union Countries and Turkey: An Empirical Analysis}

\begin{abstract}
Climate change performance of the countries is generally measured by climate change index and low carbon economy index. The aim of this article, which contains more indicators comparatively with the indices, is to determine the relative success of the European Union (EU) countries and Turkey in transition to a climate resilient and low carbon economy. Climate resilient society is the society which adapted to the negative effects of climate change. Low carbon economy is an economy which decreases greenhouse emissions. In empirical analyses, which use cluster and discriminant analyses, 23 climate change indicators issued by the EU used for 2014. Empirical findings indicate that 29 countries included in the analyses can lay out 10 different development level in terms of low carbon economy indicators. Turkey is not in the same group with any of the EU countries and constituted a unique group. The results of the discriminant analysis showed that the group which contains Turkey is the furthest group.
\end{abstract}

Keywords: Climate change indicators, climate change index, low carbon economy index, cluster analysis, discriminant analysis. 


\section{Giriş}

Dünya iklimi, insanlık tarihi boyunca önemli değişikliklere uğramıştır. Bu değişikliklerin bir bölümü doğal olarak ortaya çıarken, bir kısmı özellikle sanayi devrimi sonucunda fosil kaynak tüketimine ve nüfus artışına bağlı olarak insan kaynaklı olarak ortaya çıkmıştır. İnsan unsurunun iklim üzerindeki olumsuz etkileri, insanı da ele alan tanımların yapılmasına yol açmıştır. Bu tanımlardan en yaygın olarak kullanılanı Birleşmiş Milletlere aittir. Birleşmiş Milletler İklim Değiş̧ikliği Çerçeve Sözleşmesi (BMIDDÇS), iklim değişikliğini şu şeklide tanımlamaktadır: "Karşılaştırılabilir zaman dilimlerinde gözlenen doğal iklim değişikliklerine ek olarak, doğrudan ya da dolaylı olarak küresel atmosferin bileşimini bozan insan faaliyetleri sonucunda iklimde oluşan değişiklik”."

İklim değişikliği çeşitli olumsuz etkilere yol açmaktadır. Bunlardan bazıları; sıcaklık artışı, kuraklık, çölleşme, buz ve kar kitlelerinin erimesi, olağan dışı hava olaylarının yaşanması, biyolojik çeşitliliğin azalması, tarımsal üretimde azalma, hastalıkların artması, kıtlık ve göçün artmasıdır. ${ }^{2}$

İklim değişikliğinin olumsuz etkilerini gidermek amacıyla uluslararası düzeyde çok sayıda toplantı düzenlenmiştir. Bu konuda uluslararası alanda atılan ilk ciddi adım, 5-6 Haziran 1972 tarihlerinde Stockholm'de Birleşmiş Milletler tarafından düzenlenen Birleşmiş Milletler İnsan Çevresi Konferansıdır. Bu konferansı, 3-4 Haziran 1992 tarihlerinde Brezilya'nın Rio de Janeiro kentinde yapılan Birleşmiş Milletler Çevre ve Kalkınma Konferansı izlemiştir. Rio Konferansının on yıllık değerlendirmesini yapmak ve ileriye dönük kalkınma stratejileri belirlemek amacıyla 26 Ağustos-4 Eylül 2002 tarihleri arasında Johannesburg Zirvesi yapılmıştır. Bu girişimlerin sonuncusu, 2015 yılı Aralık ayında gerçekleştirilen Paris İklim Zirvesi'dir.

Paris Anlaşması, 195 ülke tarafından iklim değişikliğinin olumsuz etlilerini azaltmak amacıyla üzerinde görüş birliğine varılan ve hukuki bağlayıcılığı olan bir anlaşmadır. Paris anlaşması, küresel ısınmayı $2^{\circ} \mathrm{C}$ 'nin altında sınırlandırarak bütün dünyayı tehdit eden iklim değişikliği için tedbirler almayı içeren küresel bir eylem planıdır.

Paris anlaşmasını imzalayan tüm ülkeler, iklim değişikliği ile mücadele etmekte ve ulusal düzeyde çeşitli eylem planlarını uygulamaya koymaktadırlar. $\mathrm{AB}$, iklim değişikliği ile birlik düzeyinde bir mücadele sürdürmekte ve uygulamaya koyduğu eylem planları ile önemli bir örnek olarak ortaya çıkmaktadır. AB, küresel ısınma konusunu "Çevre Politikası" kapsamında ele almakta ve üye ülkelerin düşük karbonlu ve iklime dirençli bir ekonomiye geçiş sürecindeki performanslarını yayınladığı istatistiklerle ortaya koymaya çalışmaktadır. Düşük karbonlu ekonomi kavramı, karbondioksit emisyonunun minimum düzeyde olduğu ekonomiyi ifade etmektedir. İklime dirençli ekonomi kavramı ile anlatılmak istenen ise, iklim değişikliğinin olumsuz etkilerine adapte olmuş bir ekonomidir.

$\mathrm{Bu}$ makalenin konusunu; $\mathrm{AB}$ ye üye ülkelerin ve Türkiye'nin, düşük karbonlu ve iklime dirençli bir ekonomiye geçişlerinin incelenmesi oluşturmaktadır. Bu çerçevede, $\mathrm{AB}$ üyesi ülkelerin ve Türkiye'nin iklime dirençli bir ekonomiye geçiş başarıları, İklim Değişikliği Performansı Endeksinde yer alan verilerden yararlanılarak incelenmiştir. $A B$ üyesi ülkelerin ve Türkiye'nin düşük karbonlu ekonomiye geçiş performansları ise düşük karbonlu ekonominin göstergeleri ele alınarak yapılan ampirik analizlerle belirlenmiştir. Dolayısıyla, makalenin amacı, AB'ye üye ülkelerin düşük karbonlu bir ekonominin göstergeleri bakımından kaç farklı gelişme grubunda toplandıklarını ampirik olarak

1 Birleşmiş Milletler, BMi̇DÇS, Madde 1(2), 1972.

2 Aykut Başoğlu, "Küresel İklim Değişikliğinin Ekonomik Etkileri”, KTÜ Sosyal Bilimler Enstitüsü Dergisi, Sayı 7, 2014, s.178. 
ortaya koymak ve Türkiye’nin hangi üye ülkelerle benzer bir grupta yer aldığını belirlemektir. Böylece, iklim değişikliği hedeflerine ulaşmada, "çok vitesli Avrupa" (multi speed Europe) modelinde olduğu gibi farklı gelişme kutuplarının olup olmadığı belirlenmiş olacaktır. ${ }^{3}$ Çok vitesli Avrupa modeli, AB'ye üye ülkeler arasındaki yapısal ve politik farklılıkları dikkate almakta; $A B$ ülkelerinin farklı gelişme düzeylerinde toplanabileceğini kabul etmektedir. Bu modelde, öncü üye ülkelerin diğerlerinden daha önce, belirlenen mimari yapı çerçevesinde bütünleşmeleri hedeflenmektedir. ${ }^{4}$ Bulgularımız, iklim değişikliği göstergeleri bakımından farklı gruplarda (gelişme düzeylerinde) yer alan üye ülkeler için $A B$ ’nin belirleyeceği iklim değişikliği politikalarına ışık tutacaktır.

Çalışmada kümeleme ve ayırma analizleri kullanılmıştır. AB İstatistik Bürosu tarafından yayınlanan 23 gösterge kullanılarak, 28'i AB üyesi ve biri Türkiye olmak üzere 29 ülke için analizler yapılmıştır. Literatürde, $A B$ üyesi ülkelerin düşük karbonlu ve iklime dirençli bir ekonomiye geçişleri az sayıda değişkenle hesaplanan endekslerle ölçülmektedir. Makale, literatürde kullanılan endekslerin tersine, çok sayıda gösterge ile AB'ye üye ülkelerin ve Türkiye’nin iklime dirençli ve düşük karbonlu bir ekonomiye geçiş sürecindeki durumlarını ampirik analizle belirleyen ilk çalışma olması bakımından önem taşımaktadır.

Makale altı bölümden oluşmaktadır. "Giriş" kısmından sonra devam eden bölümde, AB'nin günümüzdeki iklim politikası hedefleri ele alınacaktır. İkinci bölümde, ülkelerin iklim değişikliğine ve düşük karbonlu bir ekonomiye geçiş performanslarını belirlemek amacıyla yapılan çalışmalardan oluşan literatür taraması yer almaktadır. Üçüncü bölümde, kullanılan ampirik analiz yöntemleri tanıtılırken, dördüncü bölümde analizlere dahil edilen ülkeler ve kullanılan değişkenler ele alınmıştır. Beşinci bölümde elde edilen ampirik bulgular tartışılmıştır. Altıncı bölüm "sonuç" kısmına ayrılmıştır.

\section{Avrupa Birliği'nin İklim Değişikliği Politikası}

AB'nin iklim değişikliği politikası farklı dönemler ve başlıklar altında ele alınabilir. Burada AB'nin iklim değişikliği politikasına ilişkin açıklamalar, "İlk Düzenlemeler”, "2012 Sonrası Dönem ve AB 2020 Hedefleri Kapsamındaki Düzenlemeler” ile “2030 ve 2050 Hedefleri Kapsamındaki Düzenlemeler” başlıkları altında incelenecektir.

\section{ilk Düzenlemeler}

AB’nin iklim değişikliği ile ilgili önemli ilk adımı, 1990 yılındaki Lüksemburg Çevre ve Enerji Konseyi toplantısıdır. $\mathrm{Bu}$ toplantıda sera gazı salımı ile ilgili $\mathrm{AB}$ düzeyinde hedef belirlenmiştir. $\mathrm{AB}$, attığı bu ilk adımla, 2000 yılına kadar sera gazı salımını 1990 yılı düzeylerinde tutmayı hedeflemiştir. Sonraki yıllarda AB’nin sera gazları ile ilgili yükümlülükleri, 1997 yılında Japonya'da düzenlenen konferansta imzalanan Kyoto Protokolü çerçevesinde düzenlenmiştir. Protokol, BMİDÇS’nde yer alan gelişmiş ülkelerin, 2000 yılındaki sera gazı emisyonlarını 1990 yılı seviyesine indirmelerini sağlamak amacıyla hazırlanmıştır. AB’nin Kyoto Protokolü’ndeki yükümlülüğü, AB-15 için sera gazlarını 2008-2012 döneminde 1990 düzeylerinin \%8 altına indirmek olarak ilan edilmiştir. ${ }^{5}$ AB-15 ülkeleri, Kyoto Protokolü hedeflerini belirlenen dönemde tutturmuş, hatta emisyonları ilgili dönemde 1990

3 Çok vitesli Avrupa modeli için bkz. Ziya Öniş ve Mustafa Kutlay, "Ekonomik Bütünleşme/Siyasal Parçalanmışlık Paradoksu: Avro Krizi ve Avrupa Bütünleşmesinin Geleceği”, Uluslararası İlişkiler Dergisi, Cilt 9, Sayı 33, 2012 , s.11.

4 Ibid.

5 Murat Türkeş et.al., "Kyoto Protokolü Esneklik Mekanizmaları (Flexibility Mechanisms Under the Kyoto Protocol)”, Tesisat Dergisi, Cilt 52, 2000, s.3. 
seviyesinin \%11.8 altına indirmişlerdir. Bu azaltım miktarı, Kyoto için taahhüt edilen seviyeden 1 Milyar ton $\mathrm{CO}_{2}$ eşdeğeri daha fazla olmuştur. ${ }^{6}$

AB'nin iklim değişikliği konusunda attığı adımlardan bir değeri, 2003 yılında yayınlanan 2003/87/EC sayılı yönetmelik ile kurulan, Avrupa Birliği Emisyon Ticareti Sistemi'dir (AB-ETS). $\mathrm{AB}$ üyesi ülkelerdeki işletmelerin dahil olduğu bu sistemde, emisyon seviyeleri için işletmelere yıllık kotalar verilmektedir. Yıl sonunda işletmelere tahsis edilen emisyon kotaları ile gerçekleşen emisyonlar karşılaştırılmaktadır. Yıllık emisyonu belirlenen kotanın altında kalan işletmeler, kullanmadıkları kotayı başka işletmelere satabilmektedirler. Tersine, yıllık emisyonu tahsis edilen kotanın üzerinde olan işletmeler ise başka işletmelerden emisyon fazlası satın alabilmektedirler. Bu şekilde sera gazı emisyonunun azaltılması hedeflenmiştir. ${ }^{7}$

AB’nin son dönemlerde uyguladığı iklim değişikliği politikasının temel dayanaklarından biri, Lizbon Stratejisi'dir. Lizbon Stratejisi, 23-24 Mart 2000 tarihlerinde, Portekiz’in dönem başkanlığı sırasında Lizbon'da yapılan zirve toplantısında kabul edilmiştir. Lizbon Stratejisi; 2010 yılına kadar AB'nin "daha çok sayıda ve daha iyi iş ile daha büyük bir toplumsal uzlaşmayla sürdürülebilir ekonomik büyümeyi gerçekleştirebilecek bilgiye dayalı, dünyanın en rekabetçi ve dinamik ekonomisine" dönüştürülmesini hedeflemiştir. ${ }^{8}$ Lizbon Stratejisi'nin iklim değişikliği hedefleri şu şekilde belirlenmiştir:

- Sera gazı emisyonunun, 2010 yılına kadar Kyoto Protokolü ile bağlantılı olarak, AB-15 için, 1990 yılındaki düzeyine göre \%8 azaltılması,

- Yenilenebilirkaynaklardan üretilen elektrikmiktarının, 2010yılına kadar \%22'ye çıkartılması. ${ }^{9}$

Lizbon Stratejisi ilk kez belirlendiğinde, sadece ekonomik ve sosyal hedefler üzerinde durulmuştur. İklim değişikliği ve küresel ısınma konularının gündeme gelmesi sonrasında, 15-16 Haziran 2001 tarihinde Göteborg'da düzenlenen AB zirvesinde Lizbon Stratejisi'ne çevre boyutu da eklenmiştir. Böylece, AB’nin iklim değişikliği ve küresel ısınma konularında alacağı önlemlerle daha çevreci olması hedeflenmiştir. Lizbon Stratejisinin çevresel boyutu kapsamında yukardaki somut hedefler dişında iki yan hedef belirlenmiştir. Bunlardan biri artan trafik, ses ve kirlilik ile daha etkin bir şekilde mücadele edilmesidir. Hedeflerden bir diğeri ise, doğal kaynakların sürdürülebilir kullanımının sağlanmasıdır. ${ }^{10}$

\section{Sonrası Dönem ve AB 2020 Hedefleri Kapsamındaki Düzenlemeler}

Lizbon Stratejisi'nin 2008 yılında ortaya çıkan küresel kriz sonucunda başarısız olması, AB'yi yeni bir strateji belirlemek zorunda bırakmıştır. 25 Haziran 2009 tarihinde, AB Konseyi tarafından Üçüncü Enerji Paketi kabul edilmiştir. Paket kapsamında yer alan önerilerle, düzenlemeye tabi işlemlerin kontrolünün güçlendirilmesi, alt yapı yatırımlarının teşvik edilmesi ile elektrik ve doğal

6 Etem Karakaya ve Burcu Yılmaz, “AB’nde Enerji ve İklim Değişikliği Politikalarının Gelişimi”, Pınar Gedikkaya Bal ve Rana İzci Connelly (der.), Ekonomik Kriz ve Avrupa Birliği, Ankara, Der Yayınevi, 2016, s.131-156.

7 Ibid.

8 World Economic Forum, The Lisbon Review 2008:Measuring the Europe's Progress in Reform, Geneva, World Economic Forum, 2008, s.1.

9 Simon Tilford ve Philip Whyte, The Lisbon Scorecard X the Road to 2020, London, The Centre for European Reform, 2010, farklı sayfalardan derlenmiştir.

10 Wim Kok, Facing the Challenge: The Lisbon Strategy for Growth and Employment, Report From the High Level Group, 2004, s.3. 
gaz iç piyasalarının rekabetçi, şeffaf ve güvenilir olması amaçlanmıştır. ${ }^{11}$ AB’nin Üçüncü Enerji Paketi kapsamındaki hedefleri, Lizbon Stratejisi yerine belirlediği 2020 Stratejisi'nde de devam etmiştir. Avrupa 2020 Stratejisi, Avrupa Konseyi tarafından 17 Haziran 2010 tarihinde kabul edilmiştir. AB 2020 Stratejisi ile AB'nin bilgiye ve yenilikçiliğe dayalı, üretim faktörlerini verimli kullanan, çevreci ve daha rekabetçi, yüksek istihdam sağlayan, sosyal ve bölgesel uyumu destekleyen bir ekonomiye dönüşmesi hedeflenmektedir. $\mathrm{AB}$, bu strateji ile ortaya çıkan yeni koşulları da dikkate alarak, Lizbon Stratejisi ile ulaşamadığı hedeflerine ulaşmayı planlamaktadır.

AB 2020 Stratejisi kapsamında iklim değişikliği ile ilgili aşağıdaki hedefleri belirlemiştir:

- Sera gazı salınımlarının 1990 yılı seviyesine kıyasla en az \%20 oranında azaltılması,

- Yenilenebilir enerjinin AB’nin toplam enerji tüketimi içindeki payının \%20'ye çıkarılması

- Enerji verimliliğinin \%20 artırılması. ${ }^{12}$

Yukarda belirtildiği gibi, 2020 Stratejisi çerçevesinde AB'nin sera gazı salınımı ile ilgili hedefi, 1990 yılı seviyesine göre sera gazı salınımının \%20 azaltılmasıdır. Bu nedenle, 1990 yılı baz alındığında, başka bir ifade ile 1990 yılı değeri 100 olarak kabul edildiğinde, 2020 yılına gelindiğinde AB-28'in ulaştı̆̆ı değer 80 olmalıdır. Bu nedenle, Tablo 1'in hedef sütununda 80 rakamı yer almaktadır.

Tablo 1 AB, Bazı Gelişmiş Ekonomiler ve Türkiye’de Sera Gazı Salınımı (2010-2012) -1990=100-

\begin{tabular}{|l|r|r|r|c|}
\hline Ülkeler & $\mathbf{2 0 1 0}$ & $\mathbf{2 0 1 1}$ & $\mathbf{2 0 1 2}$ & Hedef \\
\hline AB-28 & 85.73 & 83.20 & 82.13 & 80 \\
\hline Almanya & 77.06 & 75.58 & 76.55 &.. \\
\hline Avusturya & 110 & 107.56 & 104.04 &.. \\
\hline Belçika & 92.26 & 85.27 & 82.56 &.. \\
\hline Danimarka & 90.67 & 83.84 & 76.93 &.. \\
\hline Finlandiya & 106.62 & 96.49 & 88.13 &.. \\
\hline Hırvatistan & 90.27 & 89.21 & 82.65 &.. \\
\hline Hollanda & 101.43 & 94.98 & 93.26 &.. \\
\hline İtalya & 97.34 & 95.04 & 89.93 &.. \\
\hline İsveç & 90.73 & 85.12 & 80.72 &.. \\
\hline Yunanistan & 111.73 & 108.97 & 105.71 &.. \\
\hline Norveç & 108.9 & 106.67 & 105.69 &. \\
\hline İsviçre & 104.19 & 97.62 & 100.18 & \\
\hline Türkiye & 214.36 & 229.03 & 237.6 & \\
\hline
\end{tabular}

Kaynak: Eurostat.

Tablo 1 ile ilgili gözlemler şu şekilde sıralanabilir:

i) 2012 yılında, AB-28, sera gazı salımını 82.13’e kadar azaltabilmiştir. 2020 yılına kadar bu rakamın 80 'e düşürülmesi gerekmektedir.

11 Haluk Kürşat Kopuzlu, "Avrupa Birliği Üçüncü Enerji Paketi”, 3eElectrotech Dergisi, s.1, http://3eelectrotech.com.tr/ arsiv/yazi/avrupa-birlidi-3-enerji-paketi, (Erişim Tarihi 4 Ekim 2016).

12 European Union, Smarter, Greener More Inclusive: Indicators to Support the 2020 Strategy, Luxembourg, 2015, s.15. 
ii) 2012 yılı itibariyle en iyi performansı gösteren ülkeler Almanya (76.55) ve Danimarka (76.93)'dır. İsveç (80.72), Belçika (82.56), Hırvatistan (82.65) hedefe yaklaşmış olan diğer ülkelerdir.

iii) 2012 yıl itibariye, Türkiye'nin ulaştığı endeks değeri 237.6'dır. Bu değer, AB-28'in ulaştığı değerin yaklaşı üç katı kadardır.

AB’nin 2020 Stratejisi kapsamında çevre ve iklim değişikliği konusunda belirlediği ikinci hedef, “yenilenebilir enerjinin AB'nin toplam enerji tüketimi içindeki payının \%20'ye çıkarılması" şeklindedir. AB-28 için hedef \%20 iken, üye ülkelerin her biri bu konuda farklı oranlar belirlemişlerdir. Tablo 2'nin son sütunundan gözlenebileceği gibi Danimarka'nın bu konudaki hedefi \%30, Avusturya'nın bu konudaki hedefi \%34'tür. Bu ülkeler AB ortalaması üzerinde hedefler belirlerken; Belçika (\%13), Çek Cumhuriyeti (\%13) ve Bulgaristan (\%16) daha düşük hedeflerle yetinmişlerdir.

Tablo 2 AB Ülkelerinde Yenilenebilir Enerjinin Toplam Enerji Tüketimi İçindeki Payı (2010-2013) -\% olarak-

\begin{tabular}{|l|r|r|r|r|c|}
\hline Ülkeler & $\mathbf{2 0 1 0}$ & $\mathbf{2 0 1 1}$ & $\mathbf{2 0 1 2}$ & $\mathbf{2 0 1 3}$ & Hedef \\
\hline AB-28 & 12.5 & 12.9 & 14.3 & 15 & 20 \\
\hline Almanya & 10.4 & 11.4 & 12.1 & 12.4 & 18 \\
\hline Avusturya & 30.8 & 30.9 & 32.1 & 32.6 & 34 \\
\hline Belçika & 5.7 & 6.1 & 7.4 & 7.9 & 13 \\
\hline Bulgaristan & 14.1 & 14.3 & 16 & 19 & 16 \\
\hline Çek Cumhuriyeti & 9.5 & 9.5 & 11.4 & 12.4 & 13 \\
\hline Danimarka & 22 & 23.4 & 25.6 & 27.2 & 30 \\
\hline Estonya & 24.6 & 25.5 & 25.8 & 25.6 & 25 \\
\hline İlanda & 5.6 & 6.6 & 7.3 & 7.8 & 18 \\
\hline İtalya & 10.5 & 12.1 & 15.4 & 16.7 & 17 \\
\hline Türkiye &.. & 6.6 & 12.0 &.. & $20(2023$ Ylli) \\
\hline
\end{tabular}

Kaynak: AB Verisi: Eurostat. Türkiye Verisi: Türkiye Ulusal Yenilenebilir Enerji Eylem Planı.

Tablo 2'deki veriler, 2013 itibariyle, yenilenebilir enerjinin toplam enerji tüketimi içindeki payı \%15 olan AB-28'in henüz bu hedefe ulaşamadığını göstermektedir. Tablo 2'deki verilere göre, belirlediği hedefe yaklaşan ve hatta bu hedefi geçen ülkeler vardır. 2013 yılı itibariyle, Estonya'da yenilenebilir enerjinin toplam enerji tüketimi içindeki payı \%25.6'dır. Estonya'nın bu konuda belirlediği hedef ise \%25'tir. 2020 yılı için Danimarka yenilenebilir enerji tüketiminin toplam enerji tüketimi içindeki payını \%30, Avusturya ise \%34 olarak belirlemiştir. Günümüzde her iki ülke de bu hedef ulaşma yolundadır.

Türkiye, 2023 yılında yenilenebilir enerjinin toplam enerji tüketimi içindeki payının \%20 olmasını hedeflemektedir. 2012 yılı itibariyle, ulaştığı \%12'lik oran başarılı bulunabilir. Bu oran ile yenilenebilir enerjinin toplam enerji tüketimi içindeki payı \% 7,4 olan Belçika ile yenilenebilir enerjinin toplam enerji tüketimi içindeki payı \%7,3 olan İrlanda'dan daha iyi bir orana sahiptir. Yenilenebilir enerji tüketiminde istenen düzeye gelinmesi, küresel ısınma ve iklim değişikliği probleminin çözümünü kolaylaştıracaktır. 


\section{0 ve 2050 Hedefleri Kapsamındaki Düzenlemeler}

Avrupa Komisyonu tarafından hazırlanan "2030 İklim ve Enerji Paketi”, 23-24 Ekim 2014 tarihlerinde, 28 üye ülkenin devlet ve hükümet başkanlarının bir araya geldiği AB Zirvesinde onaylanmıştır. 2030 İklim ve Enerji paketi şu hedefleri içermektedir:

- 1990 yılına kıyasla, 2030 yılına kadar sera gazı emisyonlarının \%40 azaltılması;

- Yenilenebilir enerji kaynaklarının kullanım oranı ile enerji verimliliği oranının en az \%27’ye yükseltilmesi. ${ }^{13}$

$\mathrm{AB}$, iklim ve enerji paketi ile birlikte, 2021 yılında faaliyete geçmesini istediği "Pazar İstikrarı Rezervi” (Market Stability Reserve) ile bir çeşit karbon piyasası istikrar mekanizması kurma hedefindedir. Önerilen istikrar mekanizması, AB’nin 2005 yılından itibaren mevcut olan Emisyon Ticareti Sistemi ile ilgilidir.

AB 2050 Enerji Yol haritasında (COM(2011) 885 final), Avrupa enerji sistemindeki değişimin, iklim, güvenlik ve ekonomik nedenlerle kaçınılmaz olduğu, bu değişimin zamanında yapılabilmesi için AB'nin daha fazla politik kararlılığa ve hızlı hareket etme konusunda daha fazla duyarlılığa ihtiyacı olduğu belirtilmektedir. Karbon azaltım oranları ve etkileri değişik senaryolar altında incelenmiş, bütün senaryolarda azaltım oranlarının etkin olduğu ve ekonomik olarak gerçekleştirilebilir olduğu anlaşılmıştır. 2020'de \%20 olarak belirtilen gaz emisyonlarındaki düşüş oranı, 2050'de \%85-95 olarak öngörülmektedir. Yeni bulunan kaya gazının Avrupa'daki dengeleri alt üst edebileceği, bu bakımdan şimdiden önlemler alınması gerektiği, enerji arzının çeşitlendirilmesi ve yerelleştirilmesinden bahsedilmekte, komşu ülkelerle işbirliğinin geliştirilmesi gerektiğinden söz edilmektedir. ${ }^{14}$

\section{Literatür}

Ülkelerin ya da bölgelerin iklim değişikliği ile mücadele performansları çeşitli çalışmalarla ortaya konmaya çalışılmıştır. Konu ile ilgili çalışmalar iki grupta toplanabilir. Bunlardan ilk grubu, çeşitli kurumlar tarafından geliştirilen endekslerdir. İkinci grupta ise çeşitli yazarlar tarafından yapılan akademik çalışmalar bulunmaktadır. Bu nedenle, konu ile ilgili literatür; kurumlar tarafından geliştirilen endeksler ve akademik çalışmalar olmak üzere iki grupta ele alınacaktır.

\section{Kurumlar Tarafından Geliştirilen Endeksler}

$\mathrm{Bu}$ konuda geliştirilen endekslerden biri, İklim Değişikliği Performansı Endeksi (Climate Change Performance Index) olarak bilinen endekstir. ${ }^{15}$ German Watch ve Avrupa İklim Faaliyet Ağı (Climate Action Network Europe) adlı kurumlar tarafından hazırlanan endeks, 58 ülkeyi kapsamaktadır. $\mathrm{Bu}$ ülkeler; AB üyeleri, OECD üyeleri, Asya Ülkeleri ve geçiş ekonomileridir. Endekse dahil olan ülkeler, endeks değerleri bakımından dört grupta toplanmaktadır. Bu gruplar; "oldukça iyi”, "iyi”, "orta”, "zayıf”" ve "çok zayıf” şeklinde isimlendirilmektedir. Endeksin oluşturulmasında kullanılan değişkenler, Tablo 3'de yer almaktadır.

13 Melih Önsöz, “AB, 2030 İklim ve Enerji Paketi Üzerinde Anlaşmaya Vardı, Ekonomik Forum, 2014, s.64-68, http:// haber.tobb.org.tr/ekonomikforum/2014/246/064_068.pdf, (Erişim Tarihi 1 Ekim 2016).

14 European Commission, Energy Roadmap 2050, Luxembourg, European Union, 2012, s.8.

15 German Watch ve Climate Action Network Europe, The Climate Change Performance Index 2015, Brüksel, 2015, s.23. 
Tablo 3 İklim Değiş̧ikliği Performansı Endeksinde Yer Alan Değişkenler

\begin{tabular}{|c|c|}
\hline \multirow{4}{*}{$\begin{array}{l}\text { Emisyon Seviyesi } \\
\text { Göstergeleri }\end{array}$} & 1. Kişi başı birincil enerji arzı \\
\hline & 2. Kişi başı karbondioksit emisyonu \\
\hline & 3. Emisyon seviyelerinde hedef ve performans karşılaştırması \\
\hline & 4. Kişi başı azalan orman varlı̆ğından kaynaklanan karbondioksit emisyonu \\
\hline \multirow{5}{*}{$\begin{array}{l}\text { Emisyonların } \\
\text { Gelişimi }\end{array}$} & 5. Elektrik ve isı üretiminden kaynaklanan karbondioksit emisyonu \\
\hline & 6. Sanayi sektöründen kaynaklanan karbondioksit emisyonu \\
\hline & 7. Ulaştırma sektöründen kaynaklanan karbondioksit emisyonu \\
\hline & 8. Konutlardan ve binalardan kaynaklanan karbondioksit emisyonu \\
\hline & 9. Hava ulaşımından kaynaklanan karbondioksit emisyonu \\
\hline \multirow{2}{*}{$\begin{array}{l}\text { Yenilenebilir } \\
\text { Enerji }\end{array}$} & 10. Yenilenebilir enerjinin birincil enerji arzı içindeki payı \\
\hline & 11. Yenilenebilir enerji kaynaklarından elde edilen enerji arzında gelişme \\
\hline \multirow{2}{*}{ Etkinlik } & 12. Etkinlik seviyesi \\
\hline & 13. Etkinlik eğilimi \\
\hline \multirow{2}{*}{ Politika } & 14. Uluslararası iklim politikası \\
\hline & 15. Ulusal iklim politikası \\
\hline
\end{tabular}

Kaynak: German watch ve Climate Action Network Europe, The Climate Change Performance Index 2015,Brüksel, 2015 , s.23.

2015 yılı İklim değişikliği performansı endeksine göre AB üyelerinin ve Türkiye’nin durumları Tablo 4'de özetlenmiştir. Endeks değerlerine göre yapılan gruplamada Türkiye'nin AB ülkelerinden ayrıştığı gözlenmektedir (Bkz. Tablo 4).

Tablo 4 AB Üyesi Ülkeler ve Türkiye için İklim Değişikliği Endeksi Grupları

\begin{tabular}{|l|l|}
\hline Ülke Grubu & Ülkeler \\
\hline İẎ & Danimarka, İsveç, İngiltere, Portekiz, İrlanda, Fransa, Macaristan, Slovakya, Güney Kıbrıs, \\
\hline ORTA & $\begin{array}{l}\text { Belçika, İtalya, Slovenya, Malta, Litvanya, Almanya, Romanya, Çek Cumhuriyeti, İspanya, } \\
\text { Lüksemburg }\end{array}$ \\
\hline ZAYIF & $\begin{array}{l}\text { Finlandiya, Letonya, Hırvatistan, Yunanistan, Avusturya, Polonya, Bulgaristan, Hollanda, } \\
\text { Estonya }\end{array}$ \\
\hline ÇOK ZAYIF & Türkiye \\
\hline
\end{tabular}

Kaynak: German Watch ve Climate Action Network Europe, The Climate Change Performance Index 2015,Brüksel, 2015, s.24-25.

Konu ile ilgili endekslerden bir diğeri, "Düşük Karbon Ekonomisi Endeksi” (Low Carbon Economy Index $)^{16}$ olarak adlandırılan endekstir. Endeks, İngiltere'deki PWC şirketi tarafindan hazırlanmakta ve ele aldığı ülkelerde karbon yoğunluğundaki gelişmeleri yıllık olarak yayınlamaktadır.

Nian, yaptığı bir çalışmada, Çin'deki Hebei kenti için düşük karbon ekonomisi endeksi değerlendirme sistemi oluşturmaya çalışmıştır ${ }^{17}$. Endekste kullanılan değişkenler; enerji tüketim etkinliği, düşük karbon ekonomisi, düşük karbon çevresi ve insan yaşamı olmak üzere dört grupta toplanmıştır. Bu ana gruplar altında yer alan değişkenler, Tablo 5’de yer almaktadır.

16 PwC UK, www.pwc.co.uk, (Erişim Tarihi 27 Nisan 2015), s.5.

17 Yang Nian, "Low Carbon Economy Evaluation Index System and Development Evaluation of Hebei”, Sixth International Conference on Business and Financial Engineering Conference, 2013. 
Tablo 5 Düşük Karbon Ekonomisi Değerlendirme Sistemi

\begin{tabular}{|l|l|}
\hline Enerji Tüketim Etkinliği & Kişi başına enerji tüketimi \\
\hline & Kişi başına elektrik tüketimi \\
\hline & Bir birim GSYH üretmek için gerekli enerji \\
\hline & Bir birim GSYH üretmek için gerekli elektrik \\
\hline & Bir birim GSYH üretmek için kullanılan su \\
\hline & Sanayi sektörü enerji tüketiminin birim katma değeri \\
\hline & Enerji tüketim esnekliği katsayısı \\
\hline & Elektrik tüketim esnekliği katsayısı \\
\hline Düşük karbon ekonomisi & Kişi başına karbon emisyonu \\
\hline & Bir birim GSYH üretmek için gerekli karbon emisyonu \\
\hline & Karbon emisyonunun ortalama katsayısı \\
\hline Düşük karbon çevresi & Orman alanı \\
\hline & Kişi başına kent orman alanı \\
\hline İnsan yaşamı & Kişi başı çöp arıtma oranı \\
\hline & Çiftçilerin kişi başına net geliri \\
\hline & Kentte yaşayanların kişi başına kullanılabilir gelirleri \\
\hline & $\begin{array}{l}\text { Çiftçi ailelerinin Engel oranı (Bir ailenin gıda harcamalarının aile bütçesi } \\
\text { içindeki payı) }\end{array}$ \\
\hline & Kentte yaşayan ailelerin Engel oranı \\
\hline
\end{tabular}

Kaynak: Yang Nian, "Low Carbon Economy Evaluation Index System and Development Evaluation of Hebei”, Sixth International Conference on Business Intelligence and Financial Engineering, 2013.

\section{Akademik Çalışmalar}

İklim değişikliğinin ekonomik etkileri konusundaki ilk çalışmalar, ABD ile ilgili olarak Nordhaus, Cline ve Titus tarafından yapılmıştır. ${ }^{18}$ Nordhaus'un çalışmasında, $3^{\circ} \mathrm{C}$ ssınmanın ABD ekonomisinde yol açacağı etkiler incelenmiştir. Analiz sonuçları ABD’nin GSMH'sinde azalma ortaya çıkacağını göstermiştir. Ayrıca, sera gazı emisyonunun, çok az maliyetle \%10 düzeyinde azaltılabileceği hesaplanmıştır. 1991 yılında yapılan bu çalışmada, küresel çapta sera gazı emisyonunu \%10 azaltmanın, yıllık olarak iki milyar dolarlık bir maliyete yol açacağı tahmin edilmiştir. ${ }^{19}$

Cline tarafından 1992 yılında yapılan çalışmada küresel ısınmanın yol açtığı tarımsal kayıplar, deniz seviyesinde yükselme, ormanlık alanların ve suyun azalması, klima kullanımına bağlı olarak artan elektrik ihtiyacı ile ilgili tahminler yapılmış ve politika önerileri üzerinde durulmuştur. ${ }^{20}$

Titus, 1992 yılında ABD üzerine yaptığı çalışmada Cline’nin çalışmasındaki gibi küresel ısınmanın başta tarım sektörü olmak üzere, deniz seviyesi, ormanlar ve su arzı üzerindeki etkilerini incelemiştir. ${ }^{21}$ Titus tarafından yapılan çalışmanın Cline'nin çalışmasından ayrılan yanı, analizlerinde ABD'nin bütünü yerine eyaletlerine ait verileri kullanmasıdır.

18 William D. Nordhaus, "To Slow or Not to Slow: The Economics of The Greenhouse Effect”, The Economic Journal, Cilt 101, No.407, 1991, s.920-937; William R. Cline, The Economics of Global Warming, Washington DC, Institute for International Economics, 1992; James G. Titus, “The Cost of Climate Change to the United States”, Shyamal K. Majumdar et.al. (der.), Global Climate Change: Implications, Challenges and Mitigation Measures, Easton, Pennsylvania Academy of Science, 1992, s.384-409.

19 Nordhaus, "To Slow or Not to Slow".

20 Cline, The Economics of Global Warming.

21 Titus, "The Cost of Climate Change to the United States. 
ABD ile ilgili olarak yapılan bu çalışmaları, iklim değişikliğinin küresel etkilerini inceleyen diğer çalışmalarizlemiştir. Fankhauser'in 1994ve 1995 yıllarında yaptığı analizler, iklim değişikliğinin küresel etkilerini ele alan ilk çalışmalara örnek olarak verilebilir. Fankhauser, 1994 yılında yaptığı çalışmada sera gazı emisyonunun marjinal sosyal maliyetini, 1991-2000 dönemi aralığı için hesaplamıştır. ${ }^{22}$ Yazar, 1995 yılında yayınladığı kitabında ise, küresel ısınmanın farklı sektörler üzerindeki etkilerini tahmin etmiştir. Ayrıca, küresel ısınmaya bağlı olarak ortaya çıkan eko-sistem kaybının AB, ABD, SSCB, Çin ve dünyanın tamamı için maliyetini hesaplamıştır. Elde edilen bulgulara göre, 1990 yılların başında eko-sistem kaybının AB'ye maliyeti 9,750 milyon dolar, ABD'ye maliyeti 7,380 milyon dolar, SSCB'ye maliyeti 2,288 milyon dolar ve tüm dünya için maliyeti 40,530 milyon dolardır. ${ }^{23}$

Zhang, 2010 yılında yaptığı çalışmada Çin'in düşük karbon ekonomisine geçme yolunda kaydettiği gelişmeyi, düşük karbon ekonomisi göstergeleri ve Çin'in bu konuda belirlediği politikalar ışı̆̆ında ortaya koymaya çalışıştır. ${ }^{24}$ Yazarın bulguları, diğer ülkelerle karşılaştırıldığında Çin'in bu konudaki çabalarının yetersiz olduğunu ortaya koymuştur.

Biesbroek et.al. 2010 yılında yaptıkları çalışmada, AB'ye üye ülkelerin iklim değişikliğine adaptasyon stratejilerini karşılaştırmıştır. Yazarların bulguları, üye ülkelerin politika uygulamalarında ciddi engellerin bulunduğunu ortaya koymuştur. ${ }^{25}$

Tompkins ve diğerleri, İngiltere üzerine yaptıkları çalışmada, İngiltere’nin iklim değişikliğine ne ölçüde adapte olduğunu incelemişlerdir. Yazarlar, İngiltere'de iklim değişikliğine uyum sağlama çabalarının genellikle devletin girişimi ile gerçekleştirildiğine dikkat çekmişlerdir. Ayrıca, İngiltere'de yapılan çalışmaların çoğunun iklim değişikliğinin ekonomik etkilerinin belirlenmesi üzerinde yoğunlaştığını gözlemlemişlerdir. ${ }^{26}$

Schelinhuber, yaptığı çalışmada iklim değişikliğinin Avrupa üzerindeki fiziksel ve ekonomik etkilerini incelemiştir. ${ }^{27}$ Yazar, iklim değişikliğinin Avrupa'ya etkilerini "tarımsal üretim", "akarsular", "sahiller" ve "turizm” üzerindeki etkileri bakımından ele almıştır. Çalışmada elde edilen bulgular, Avrupa’nın güneyinin, turizm ve tarım sektörleri bakımından iklim değişikliğinden Avrupa’nın kuzeyine göre daha fazla etkileneceğini göstermiştir.

\section{Araştırma Yöntemi}

Ampirik analizde iki yöntem kullanılmıştır. Bunlardan birincisi kümeleme analizi, diğeri ayırma analizidir. Bu analizler sırasıyla kısaca tanitılacaktır.

Kümeleme analizi, $\mathrm{X}$ veri matrisinde yer alan ve doğal grupları tam olarak bilinmeyen grupları birbirine benzeyen alt gruplara ayırmada kullanılan yöntemler topluluğudur ${ }^{28}$. Hiyerarşik kümeleme

22 Samuel Fankhauser, “The Social Costs of Greenhouse Gas Emissions: An Expected Value Approach”, Energy Journal, Cilt 15, No.2, 1994, s.157-184.

23 Samuel Fankhauser, Valuing Climate Change: The Economics of the Greenhouse, London, Earth scan Publication Ltd., 1995, s.34.

24 Zhong Xian Zhang, “China in Transition to A Low-Carbon Economy”, Energy Policy, No.38, 2010, s.6638-6653.

25 G.Robbert Biesbroek et.al., "Europe Adapts to Climate Change: Comparing national Adaption Strategies”, Global Environmental Change, No.20, 2010, s.441.

26 Emma L. Tompkins et.al., "Observed Adaption to Climate Change: UK Evidence of Transition to a Well-Adapting Society”, Global Environmental Change, Cilt 20, 2010, s. 627.

27 Hans-Joachim Schelinhuber, "Physical and Economic Consequences of Climate Change in Europe", Proceedings of the national Academy of Science, 15 Şubat 2011, s.4, http://www.pnas.org/content/108/7/2678.full, (Erişim Tarihi 26 Nisan 2016).

28 Kazım Özdamar, Paket Programlar ile İstatistiksel Veri Analizi-2:Çok Değişkenli Analiz (SPSS, MİNİTAB), Eskişehir, Kaan Kitabevi, 2004, s.279. 
analizi ile hiyerarşik olmayan kümeleme analizi olmak üzere iki yöntem kullanılabilmektedir. Hiyerarşik olmayan kümeleme analizi k-ortalamalar kümesi (K-means clustering) yöntemidir. ${ }^{29}$

Çok değişkenli analiz yöntemlerinden biri olan kümeleme analizini kullanarak, ülkelerin bir grup gösterge bakımından göreli gelişme düzeylerinin ölçülmesini hedef alan çok sayıda çalışma vardır. ${ }^{30} \mathrm{Bu}$ çalışma, $\mathrm{AB}$ üyesi ülkelerin ve Türkiye'nin düşük karbonlu ve iklime dirençli bir topluma geçişte göreli durumlarını ortaya koymayı amaçlaması bakımından, literatürde bu yöntemi kullanmış olan çalışmalarla benzerlik göstermektedir.

Bu çalışmada hiyerarşik kümeleme analizi kullanılmıştır. Hiyerarşik kümelemede en yaygın kullanılan yöntemlerden biri, hiyerarşik yığmacı (hierarchical agglomerative) yöntemdir. Bu yöntem ilk olarak bütün gözlemleri tek bir kümede toplamakta; daha sonra, bu kümeye en aykırı olan gözlemleri teker teker kümeden uzaklaştırarak başka kümelerin oluşmasını sağlamaktadır. Yığmacı yöntem: Bağlantı yöntemleri, Ward Yöntemi ve Merkez Yöntemi olmak üzere üç alt grupta toplanmaktadır. $\mathrm{Bu}$ yöntemler içerisinde en yaygın kullanılanı Ward Yöntemidir. Bu makalede de Ward Yöntemi tercih edilmiştir. Ward Yöntemi ile kümeleme analizi yapılmadan önce, farklı ölçü birimleri ile ifade edilen veriler standartlaştırılmıştır. Bunun nedeni, analizde kullanılan tüm değişkenlere ait verilerin aynı ölçü birimi ile ölçülmemiş olmasıdır. Örneğin, bazı verilerin "ton", bazılarının "dolar” ve bazılarının "yüzde" olarak ifade edilmesi, hatalı sonuçların ortaya çıkmasına yol açabilir. Bu durumu önlemek amacıyla, analizde kullanılan tüm değişkenler standartlaştırılarak aynı ölçü birimine dönüştürülmüş olur. Makalede, analize dahil edilen ülkeler, düşük karbonlu ve iklime dirençli bir ekonominin göstergelerinden yararlanılarak, benzer özellikleri itibariyle gruplandırılmıştır.

Ayırma analizi, çok değişkenli istatistiksel analiz yöntemlerinden biridir. Kullanılan değişkenler "bağımlı" ve "bağımsız" olmak üzere iki grupta toplanmaktadır. Ayırma analizi şu amaçlarla kullanılmaktadır: ${ }^{31}$

i) Önceden belirlenen grupları birbirinden en iyi ayıran tahmin edici değişkenlerin doğrusal kombinasyonlarının belirlenmesi.

ii) Değişkenler itibariyle gruplar arasında bir farkın olup olmadığının test edilmesi.

iii) Gruplar arası farkı en iyi belirleyen bağımsız değişkenin tespit edilmesi.

iv) Eldeki gözlemleri yeniden gruplara atayarak, tahminlerin doğru yapılıp yapılmadığını test etmek.

v) Dışardan alınan bir gözlemin, ayırma fonksiyonu aracılığı ile hangi gruba dahil olduğunun belirlenmesi.

Bu çalışmada, ayırma analizi dördüncü amaç doğrultusunda, kümeleme analizi sonuçlarının doğruluğunu test etmek için kullanılmıştır.

\section{Analize Dâhil Edilen Ülkeler ve Değişkenler}

Analizlerimize 29 ülke dâhil edilmiştir. Türkiye dışındaki 28 ülke AB'nin bugünkü tam üyeleridir. $\mathrm{Bu}$ ülkeler; Belçika, Bulgaristan, Çek Cumhuriyeti, Danimarka, Almanya, Estonya, İrlanda, Yunanistan,

29 Mahir Nakip, Pazarlama Araştırmaları: Teknikler ve SPSS Destekli Uygulamalar, Ankara, Seçkin Yayınevi, 2003 , s.438.

30 Bu konudaki çalışmalar için Bkz. Hayriye Atik, “Türkiye’de 6360 ve 6447 Sayılı Kanunlarla Kurulan Büyükşehirlerin Göreli kalkınma Düzeyleri”, TİSK Akademi, Cilt 10, No.20, 2015, s.371-389.

31 Nakip, Pazarlama Araştırmaları, s.461. 
İspanya, Fransa, İtalya, Kıbrıs, Letonya, Litvanya, Lüksemburg, Macaristan, Malta, Hollanda, Avusturya, Polonya, Portekiz Romanya, Slovenya, Slovakya, Finlandiya, İsveç, İngiltere'dir.

Analizlerimizde 23 değişken kullanılmıştır (Bkz. Tablo 6). Bu değişkenlere ait veriler, AB tarafından yayınlanan iklim değişikliği ve karbon istatistiklerinden derlenmiştir.

Tablo 6 Kümeleme ve Ayırma Analizlerinde Kullanılan Değişkenler

\begin{tabular}{|c|c|c|}
\hline Gösterge & Yil & Ölçü Birimi \\
\hline 1. Birincil enerji tüketimi & 2014 & $2005=100$ \\
\hline 2. Kişi başı brüt yurt-içi enerji tüketimi & 2014 & 1000 ton petrol eşdeğeri \\
\hline 3. Kişi başı yurt-içi katı yakıt tüketimi & 2014 & 1000 ton petrol eşdeğeri \\
\hline 4.Kişi başı brüt toplam petrol ürünleri tüketimi & 2014 & 1000 ton petrol eşdeğeri \\
\hline 5.Kişi başı brüt toplam yurt-içi gaz tüketimi & 2014 & 1000 ton petrol eşdeğeri \\
\hline 6. Kişi başı brüt yurt-içi nükleer ısı tüketimi & 2014 & 1000 ton petrol eşdeğeri \\
\hline 7. Kişi başı brüt yurt-içi yenilenebilir enerji tüketimi & 2014 & 1000 ton petrol eşdeğeri \\
\hline 8. Kişi başı brüt yurt-içi yenilenemeyen enerji tüketimi & 2014 & 1000 ton petrol eşdeğeri \\
\hline 9. Toplam enerji bağımlılığı & 2014 & Yüzde \\
\hline 10.Katı yakıtlarda enerji bağımlılığı & 2014 & Yüzde \\
\hline 11. Petrol ürünlerinde enerji bağımlılığı & 2014 & Yüzde \\
\hline 12.Doğal gazda enerji bağımlılığı & 2014 & Yüzde \\
\hline 13. Sera gazı emisyonu & 2014 & 1990=100, (CO2 eşdeğeri) \\
\hline $\begin{array}{l}\text { 14. Hava ulaşımı dışındaki sektörlerde sera gazı } \\
\text { emisyonu }\end{array}$ & 2014 & $1990=100,(\mathrm{CO} 2$ eşdeğeri) \\
\hline 15.Tüm sektörlerde kişi başına düşen sera gazı emisyonu & 2014 & Milyon ton (CO2 eşdeğeri) \\
\hline $\begin{array}{l}\text { 16. Enerji sektöründen kaynaklanan kişi başı sera gazı } \\
\text { emisyonu }\end{array}$ & 2014 & Milyon ton (CO2 eşdeğeri) \\
\hline $\begin{array}{l}\text { 17. İmalat ve inşaat sektörlerinden kaynaklanan } \\
\text { kişi başı sera gazı emisyonu }\end{array}$ & 2014 & Milyon ton (CO2 eşdeğeri) \\
\hline $\begin{array}{l}\text { 18. Ulaştırma sektöründen kaynaklanan kişi başı sera } \\
\text { gazı emisyonu }\end{array}$ & 2013 & Milyon ton (CO2 eşdeğeri) \\
\hline $\begin{array}{l}\text { 19. Endüstriyel üretimden kaynaklanan kişi başı sera } \\
\text { gazı emisyonu }\end{array}$ & 2013 & Milyon ton (CO2 eşdeğeri) \\
\hline $\begin{array}{l}\text { 20. Tarım sektöründen kaynaklanan kişi başı sera gazı } \\
\text { emisyonu }\end{array}$ & 2013 & Milyon ton (CO2 eşdeğeri) \\
\hline 21. Atıklardan kaynaklanan kişi başı sera gazı emisyonu & 2013 & Milyon ton (CO2 eşdeğeri) \\
\hline 22.Enerji tüketiminden kaynaklanan sera gazı yoğunluğu & 2013 & $\begin{array}{l}2000=100 \\
\text { (Enerji tüketiminden kaynaklanan } \\
\text { sera gazı miktarının toplam yurt-içi } \\
\text { enerji tüketimine oranlanması ile } \\
\text { hesaplanmıstır.) } \\
\end{array}$ \\
\hline 23. Yenilenebilir enerjinin enerji tüketimi içindeki payı & 2013 & Yüzde olarak \\
\hline
\end{tabular}

Göstergelerin bir bölümü, ülkelerin nüfusları kullanılarak kişi başı değere çevrilerek analize dahil edilmişve Tablo 6'da “kişi başı” şeklinde ifade edilmiştir. Verilerin kişi başı rakama dönüştürülerek kullanılmasının nedeni, yapacağımız analizlerin ve karşılaştırmaların sağlıklı olabilmesi içindir. AB üyesi ülkelerin nüfusları birbirine eşit olmadığı için toplam değerler üzerinden ülkelerin performanslarını belirlemek mümkün değildir. 


\section{Ampirik Bulgular}

\section{Kümeleme Analizi}

Hiyerarşik kümeleme analizi iki şekilde uygulanmıştır. İlk aşamada küme sayısı belirtilmeden Ward Yöntemi kullanılarak analiz yapılmış ve Şekil 1'de yer alan ağaç grafiği elde edilmiştir. İkinci aşamada ise küme sayısı belirtilerek analiz yapılmıştır.

Şekil 1'de yer alan ağaç grafiği, ele alınan ülkelerin iklime dirençli ve düşük karbonlu ekonomiye geçiş göstergeleri bakımından on farklı grupta toplanabileceğini ortaya koymaktadır. Tablo 7'de yer alan yığışım tablosunda, katsayıların 19., aşamasından itibaren önceki aşamalara göre on büyük sıçrama olduğu görülmektedir. Bu katsayılar: 185,397, 210,118, 238,913, 276,499, 317,553, 360,564, 413,924, 484,315, 561,643 ve 644,000'dir. Katsayılardaki sıçrama sayısı, kümeleme analizinde küme sayısını vermektedir. Bu nedenle, on kümenin varlığından bahsedebiliriz. Başka bir ifade ile, analizlere dahil edilen 29 ülke, ele alınan iklim değişikliği ve düşük karbonlu bir ekonomiye geçiş göstergeleri bakımından on grupta toplanmaktadır. Her bir grupta yer alan ülkeler benzer performans düzeyi sergilemektedirler. Farklı gruplarda yer alan ülkeler ise, farklı performans düzeylerindedirler. Ağaç grafiğinden elde edilen küme üyelikleri Tablo 8'de sunulmuştur.

Tablo 7 Yığışım Tablosu

\begin{tabular}{|c|c|c|c|c|c|c|}
\hline \multirow{2}{*}{ Aşama } & \multicolumn{2}{|c|}{ Birleştirilen Küme } & \multirow{2}{*}{ Katsayılar } & \multicolumn{2}{|c|}{$\begin{array}{c}\text { Kümenin İlk Ortaya Çıktığı } \\
\text { Asama }\end{array}$} & \multirow{2}{*}{$\begin{array}{c}\text { Sonraki } \\
\text { Aşama }\end{array}$} \\
\hline & Küme 1 & Küme 2 & & Küme 1 & Küme 2 & \\
\hline 1 & 9 & 12 & 2,222 & 0 & 0 & 2 \\
\hline 2 & 9 & 22 & 5,316 & 1 & 0 & 17 \\
\hline 3 & 2 & 17 & 9,606 & 0 & 0 & 9 \\
\hline 4 & 11 & 14 & 14,325 & 0 & 0 & 11 \\
\hline 5 & 5 & 24 & 19,082 & 0 & 0 & 6 \\
\hline 6 & 5 & 21 & 24,679 & 5 & 0 & 10 \\
\hline 7 & 23 & 28 & 31,320 & 0 & 0 & 16 \\
\hline 8 & 1 & 20 & 38,450 & 0 & 0 & 19 \\
\hline 9 & 2 & 8 & 46,047 & 3 & 0 & 13 \\
\hline 10 & 3 & 5 & 54,441 & 0 & 6 & 14 \\
\hline 11 & 11 & 15 & 63,230 & 4 & 0 & 13 \\
\hline 12 & 10 & 25 & 72,614 & 0 & 0 & 14 \\
\hline 13 & 2 & 11 & 84,533 & 9 & 11 & 17 \\
\hline 14 & 3 & 10 & 96,577 & 10 & 12 & 20 \\
\hline 15 & 13 & 18 & 109,001 & 0 & 0 & 25 \\
\hline 16 & 4 & 23 & 126,404 & 0 & 7 & 22 \\
\hline 17 & 2 & 9 & 144,556 & 13 & 2 & 20 \\
\hline 18 & 26 & 27 & 164,832 & 0 & 0 & 23 \\
\hline 19 & 1 & 19 & 185,397 & 8 & 0 & 21 \\
\hline 20 & 2 & 3 & 210,118 & 17 & 14 & 22 \\
\hline 21 & 1 & 7 & 238,913 & 19 & 0 & 24 \\
\hline 22 & 2 & 4 & 276,499 & 20 & 16 & 24 \\
\hline 23 & 6 & 26 & 317,553 & 0 & 18 & 26 \\
\hline 24 & 1 & 2 & 360,564 & 21 & 22 & 25 \\
\hline 25 & 1 & 13 & 413,924 & 24 & 15 & 27 \\
\hline 26 & 6 & 29 & 484,315 & 23 & 0 & 27 \\
\hline 27 & 1 & 6 & 561,643 & 25 & 26 & 28 \\
\hline 28 & 1 & 16 & 644,000 & 27 & 0 & 0 \\
\hline
\end{tabular}


Şekil 1 Ward Yöntemiyle Elde Edilen Ağaç Grafiği

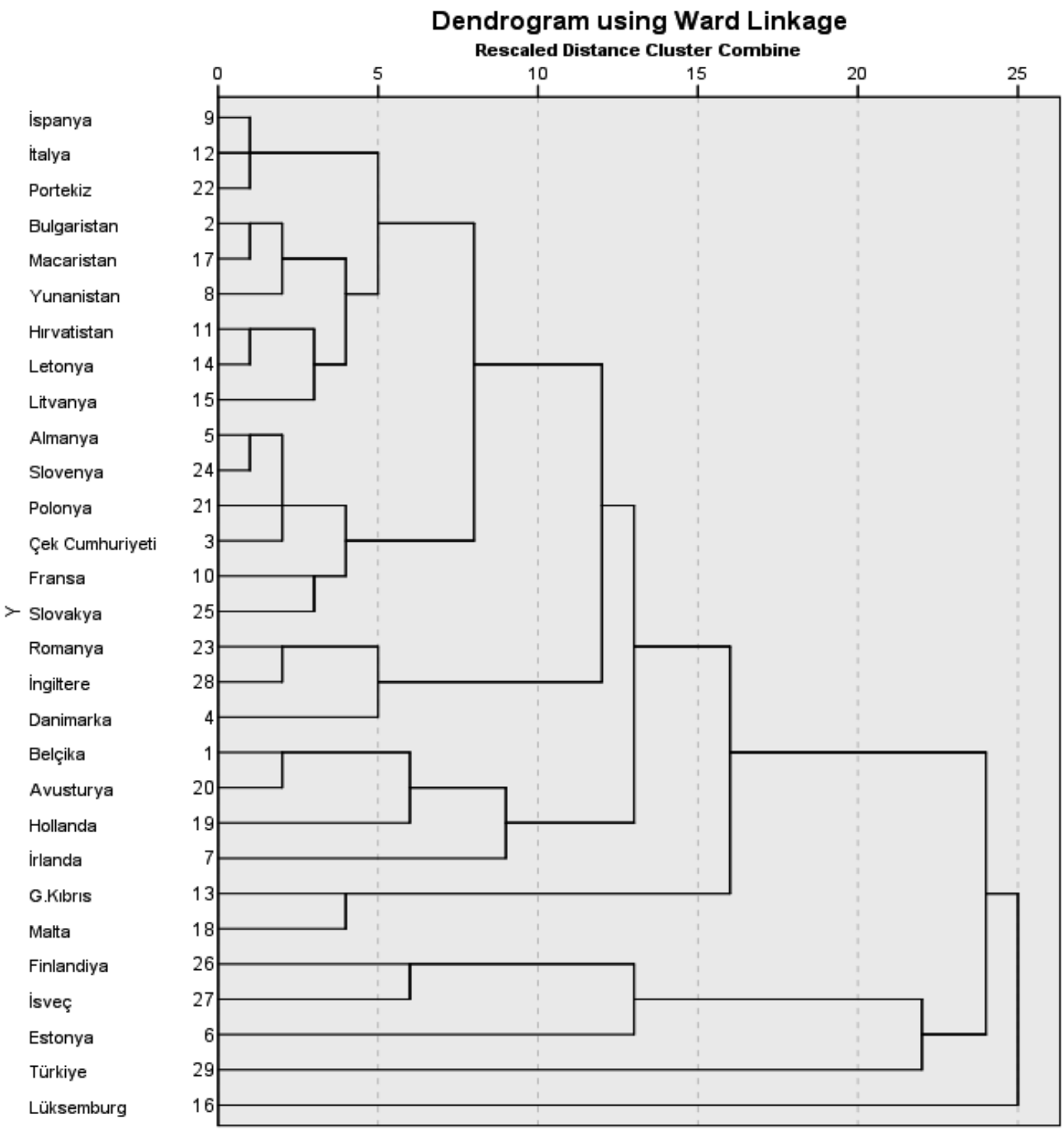

Tablo 8 Ağaç Grafiğinden Elde Edilen Küme (Grup) Üyelikleri

\begin{tabular}{|l|l|}
\hline Küme (Grup) Numarası & Kümeye Dahil Olan Ülkeler \\
\hline Küme 1 & Belçika, Avusturya, Hollanda \\
\hline Küme 2 & $\begin{array}{l}\text { İspanya, İtalya, Portekiz, Bulgaristan, Macaristan, Yunanistan, Hırvatistan, } \\
\text { Letonya, Litvanya }\end{array}$ \\
\hline Küme 3 & Almanya, Slovenya, Polonya, Çek Cumhuriyeti, Fransa, Slovakya \\
\hline Küme 4 & Romanya, İngiltere, Danimarka \\
\hline Küme 5 & Estonya \\
\hline Küme 6 & İrlanda \\
\hline Küme 7 & Güney Kıbris, Malta \\
\hline Küme 8 & Lüksemburg \\
\hline Küme 9 & Finlandiya, Isveç \\
\hline Küme 10 & Türkiye \\
\hline
\end{tabular}


Tablo 9 Küme Sayısı Belirtilerek Yapılan Analizde Elde Edilen Küme Üyelikleri

\begin{tabular}{|c|c|c|c|c|c|c|}
\hline Ülkeler & $\begin{array}{c}10 \text { Küme } \\
\text { Olursa }\end{array}$ & $\begin{array}{c}9 \text { Küme } \\
\text { Olursa }\end{array}$ & $\begin{array}{l}8 \text { Küme } \\
\text { Olursa }\end{array}$ & $\begin{array}{l}7 \text { Küme } \\
\text { Olursa }\end{array}$ & $\begin{array}{c}6 \text { Küme } \\
\text { Olursa }\end{array}$ & $\begin{array}{l}5 \text { Küme } \\
\text { Olursa }\end{array}$ \\
\hline Belçika & 1 & 1 & 1 & 1 & 1 & 1 \\
\hline Bulgaristan & 2 & 2 & 2 & 2 & 2 & 1 \\
\hline Çek Cum. & 3 & 2 & 2 & 2 & 2 & 1 \\
\hline Danimarka & 4 & 3 & 3 & 2 & 2 & 1 \\
\hline Almanya & 3 & 2 & 2 & 2 & 2 & 1 \\
\hline Estonya & 5 & 4 & 4 & 3 & 3 & 2 \\
\hline İrlanda & 6 & 5 & 1 & 1 & 1 & 1 \\
\hline Yunanistan & 2 & 2 & 2 & 2 & 2 & 1 \\
\hline İspanya & 2 & 2 & 2 & 2 & 2 & 1 \\
\hline Fransa & 3 & 2 & 2 & 2 & 2 & 1 \\
\hline Hirvatistan & 2 & 2 & 2 & 2 & 2 & 1 \\
\hline İtalya & 2 & 2 & 2 & 2 & 2 & 1 \\
\hline Güney Kıbrıs & 7 & 6 & 5 & 4 & 4 & 3 \\
\hline Letonya & 2 & 2 & 2 & 2 & 2 & 1 \\
\hline Litvanya & 2 & 2 & 2 & 2 & 2 & 1 \\
\hline Lüksemburg & 8 & 7 & 6 & 5 & 5 & 4 \\
\hline Macaristan & 2 & 2 & 2 & 2 & 2 & 1 \\
\hline Malta & 7 & 6 & 5 & 4 & 4 & 3 \\
\hline Hollanda & 1 & 1 & 1 & 1 & 1 & 1 \\
\hline Avusturya & 1 & 1 & 1 & 1 & 1 & 1 \\
\hline Polonya & 3 & 2 & 2 & 2 & 2 & 1 \\
\hline Portekiz & 2 & 2 & 2 & 2 & 2 & 1 \\
\hline Romanya & 4 & 3 & 3 & 2 & 2 & 1 \\
\hline Slovenya & 3 & 2 & 2 & 2 & 2 & 1 \\
\hline Slovakya & 3 & 2 & 2 & 2 & 2 & 1 \\
\hline Finlandiya & 9 & 8 & 7 & 6 & 3 & 2 \\
\hline İsveç & 9 & 8 & 7 & 6 & 3 & 2 \\
\hline İngiltere & 4 & 3 & 3 & 2 & 2 & 1 \\
\hline Türkiye & 10 & 9 & 8 & 7 & 6 & 5 \\
\hline
\end{tabular}

Küme sayısı, ağaç grafiğinden yararlanılarak en az beş en fazla 10 şeklinde belirlenerek analiz tekrarlanmış ve elde edilen sonuçlar Tablo 9'da sunulmuştur. Tablo 9'da her bir küme sütunu itibariyle ülkelerin karşısında yer alan rakamlar, ülkelerin dahil olacakları kümeleri göstermektedir. Buna göre, beş küme olması durumunda Belçika, Bulgaristan, Çek Cumhuriyeti, Danimarka, Almanya, İrlanda, Yunanistan, İspanya, Fransa, Hırvatistan, İtalya, Letonya, Litvanya, Macaristan, Hollanda, Avusturya, Polonya, Portekiz, Romanya, Slovenya, Slovakya ve İngiltere birinci kümede yer alacak ülkelerdir. Bu çözüme göre; Estonya, Finlandiya ve İsveç ikinci kümeyi oluşturacaktır. Güney Kıbrıs ve Malta üçüncü kümede yer alırken; Lüksemburg dördüncü kümede, Türkiye beşinci kümede yer alacaktır. Ülkelerin büyük bir bölümünü yoğun olarak tek kümede toplayan bu çözüm pek anlamlı gelmemektedir. On küme dışındaki diğer yaklaşımlar da, aynen beş küme olması durumu gibi ağaç grafiği ile tutarlı sonuçlar vermemektedir. Bu nedenle, küme sayısını belirterek yaptığımız analiz sonucunda da on küme olması durumunu kabul edebiliriz. 


\section{Ayırma Analizi Sonuçları}

Ayırma analizi, daha önce de belirttiğimiz gibi kümeleme analizi sonuçlarını test etmek amacıyla yapılmıştır. Başka bir ifade ele aldığımız göstergeler bakımından $A B$ üyesi ülkeleri doğru gruplandırıp gruplandırmadığımızı ortaya koymayı amaçlamaktadır. Tablo 10'da ayırma analizi sonuçları görünmektedir. 23 değişken ve ülkelerin dahil oldukları küme numaraları arasında yaptığımız ayırma analizine göre sınıflama \%100 doğru sonuç vermiştir. Başka bir ifade ile kümeleme analizi sonucunda elde edilen küme üyelikleri "orijinal” küme üyelikleri olarak kabul edildiğinde, ayırma analizi sonucunda elde ettiğimiz tahmini küme üyelikleri, orijinal küme üyelikleri ile aynı çıkmıştır. Tablo 10 'da yer alan toplam sütunu her bir kümede yer alan üye sayısını göstermektedir. Tablo 10`daki bu sayılarla Tablo 8'deki kümelerin üye sayıları eşittir.

Tablo 10 Ayırma Analizi Sonuçları

\begin{tabular}{|c|c|c|c|c|c|c|c|c|c|c|c|c|}
\hline \multirow{2}{*}{$\begin{array}{c}\text { Orijinal } \\
\text { Sayı }\end{array}$} & \multirow{2}{*}{$\begin{array}{c}\text { Küme } \\
\text { Numarası }\end{array}$} & \multicolumn{10}{|c|}{ Tahmin Edilen Grup Üyelikleri ${ }^{\text {a }}$} & \multirow{2}{*}{ Toplam } \\
\hline & & 1 & 2 & 3 & 4 & 5 & 6 & 7 & 8 & 9 & 10 & \\
\hline & 1 & 3 & 0 & 0 & 0 & 0 & 0 & 0 & 0 & 0 & 0 & 3 \\
\hline & 2 & 0 & 9 & 0 & 0 & 0 & 0 & 0 & 0 & 0 & 0 & 9 \\
\hline & 3 & 0 & 0 & 6 & 0 & 0 & 0 & 0 & 0 & 0 & 0 & 6 \\
\hline & 4 & 0 & 0 & 0 & 3 & 0 & 0 & 0 & 0 & 0 & 0 & 3 \\
\hline & 5 & 0 & 0 & 0 & 0 & 1 & 0 & 0 & 0 & 0 & 0 & 1 \\
\hline & 6 & 0 & 0 & 0 & 0 & 0 & 1 & 0 & 0 & 0 & 0 & 1 \\
\hline & 7 & 0 & 0 & 0 & 0 & 0 & 0 & 2 & 0 & 0 & 0 & 2 \\
\hline & 8 & 0 & 0 & 0 & 0 & 0 & 0 & 0 & 1 & 0 & 0 & 1 \\
\hline & 9 & 0 & 0 & 0 & 0 & 0 & 0 & 0 & 0 & 2 & 0 & 2 \\
\hline & 10 & 0 & 0 & 0 & 0 & 0 & 0 & 0 & 0 & 0 & 1 & 1 \\
\hline \multirow{10}{*}{$\%$} & 1 & 100 & 0 & 0 & 0 & 0 &, 0 & 0 & 0 &, 0 & , 0 & 100,0 \\
\hline & 2 & , 0 & 100 & ,0 & , 0 & , 0 &, 0 & , 0 & , 0 &, 0 & , 0 & 100,0 \\
\hline & 3 & 0 & , 0 & 100 & 0 & 0 &, 0 &, 0 & 0 &, 0 & 0 & 100,0 \\
\hline & 4 & , 0 &, 0 & , 0 & 100 &, 0 &, 0 &, 0 & , 0 &, 0 & , 0 & 100,0 \\
\hline & 5 & 0 & , 0 & 0 & 0 & 100 &, 0 & 0 & 0 &, 0 & 0 & 100,0 \\
\hline & 6 & 0 &, 0 & , 0 &, 0 & , 0 & 100 &, 0 & , 0 &, 0 & 0 & 100,0 \\
\hline & 7 & , 0 &, 0 & , 0 & , 0 & , 0 &, 0 & 100 & , 0 &, 0 & 0 & 100,0 \\
\hline & 8 & , 0 & , 0 & 0 & 0 & , 0 &, 0 & , 0 & 100 & , 0 & , 0 & 100,0 \\
\hline & 9 & , 0 &, 0 & , 0 & , 0 & 0 &, 0 &, 0 & , 0 & 100 & 0 & 100,0 \\
\hline & 10 & 0 & , 0 & 0 & 0 &, 0 &, 0 &, 0 & 0 &, 0 & 100 & 100,0 \\
\hline & & \multicolumn{11}{|c|}{ a Orijinal kümelere göre $\% 100$ doğru sonuç vermiştir. } \\
\hline
\end{tabular}


Şekil 2 Ayırma Fonksiyonuna Göre Küme Merkezleri ve Küme Elemanlarının Dağılımı

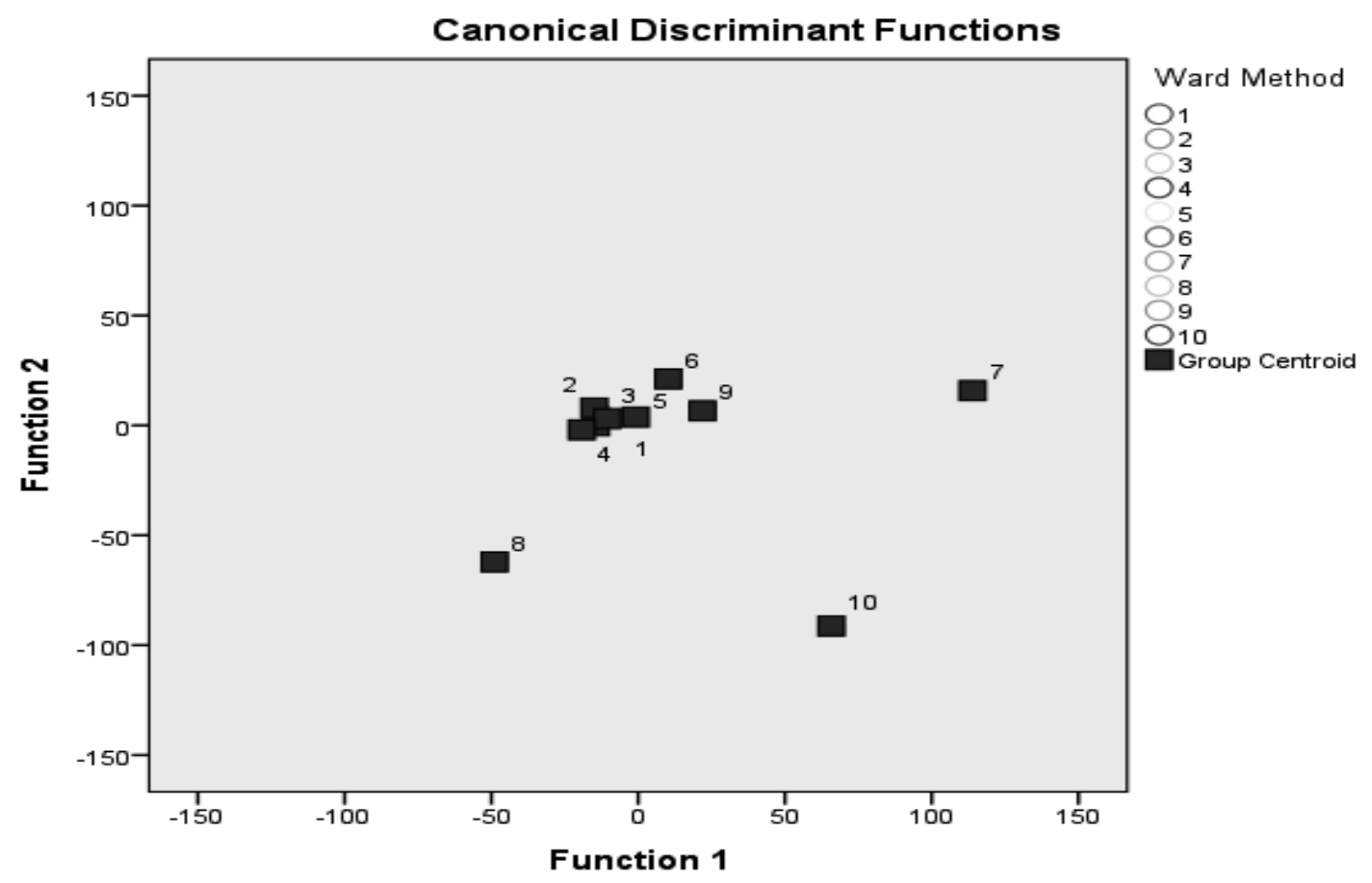

Şekil 2'de on kümenin birbirine uzaklıkları görülmektedir. Birinci, ikinci, üçüncü, dördüncü ve beşinci kümeler birbirine en yakın kümelerdir. Altıncı ve dokuzuncu kümeler ilk beş kümenin biraz uzağında yer almaktadırlar. Yedinci (Güney Kıbrıs, Malta), sekizinci (Lüksemburg) ve onuncu (Türkiye) kümeler diğerlerine en uzak kümelerdir. Diğer kümelerden uzak olan kümeler, iklime dirençli ve düşük karbonlu bir ekonomiye geçiş göstergeleri bakımından diğer kümelerden oldukça farklı bir performans sergilemektedirler. Türkiye ile ilgili bu bulgumuz, literatürdeki iklim değişikliği endeksi 2015 yılı bulguları ile örtüşmektedir. 2015 yılı iklim değişikliği endeksinde, Türkiye'nin "çok zayıf” olarak adlandırılan grupta yer aldığı ifade edilmişti (Bkz. Tablo 4). 
Tablo 11 Grup Ortalamalarının Eşitliği Testi

\begin{tabular}{|l|r|r|r|r|r|}
\hline Kısaltılmış Değişken Adı & Wilks' Lambda & \multicolumn{1}{|c|}{ F } & df1 & df2 & Anlamlılık \\
\hline (Birincil enerji) &, 116 & 16,059 & 9 & 19 &, 000 \\
(Brüt enerji kişi başı) &, 081 & 23,860 & 9 & 19 &, 000 \\
(katı yakıt kişi başı) &, 173 & 10,122 & 9 & 19 &, 000 \\
(Brüt petrol ürün kişi başı) &, 105 & 18,072 & 9 & 19 &, 000 \\
(kişi başı gaz) &, 277 & 5,524 & 9 & 19 &, 001 \\
(kişi nükleer ısı) &, 378 & 3,468 & 9 & 19 &, 011 \\
(kişi yenilenebilir) &, 208 & 8,035 & 9 & 19 &, 000 \\
(kişi başı çöp) &, 535 & 1,835 & 9 & 19 &, 127 \\
(bağımlılık toplam) &, 291 & 5,145 & 9 & 19 &, 001 \\
(bağımlılık katı) &, 693 &, 937 & 9 & 19 &, 517 \\
(bağım petrol) &, 174 & 10,047 & 9 & 19 &, 000 \\
(bağımllılk gaz) &, 438 & 2,710 & 9 & 19 &, 032 \\
(sera gazı emisyonu) &, 400 & 3,167 & 9 & 19 &, 016 \\
(sera gazı hava hariç) &, 379 & 3,459 & 9 & 19 &, 011 \\
(tüm sektör kişi başı sera) &, 186 & 9,249 & 9 & 19 &, 000 \\
(kişi başı enerji sektörü sera) &, 542 & 1,783 & 9 & 19 &, 138 \\
(kişi başı inşaat ve imalat sera) &, 017 & 122,144 & 9 & 19 &, 000 \\
(kişi başı ulaştırma sera) &, 038 & 53,010 & 9 & 19 &, 000 \\
(kişi başı endüstriyel üretim) &, 589 & 1,474 & 9 & 19 &, 227 \\
(kişi başı tarımsal sera) &, 151 & 11,880 & 9 & 19 &, 000 \\
(yoğunluk) &, 293 & 5,104 & 9 & 19 &, 001 \\
(yenilenebilir tüketim payı) &, 216 & 7,648 & 9 & 19 &, 000 \\
\hline
\end{tabular}

Tablo 11'de, Analizlerimizde kullandığımız 23 değişken için küme ortalamalarının farklı olup olmadığı gözlenmektedir. Tablo 11'in ilk sütununda, ampirik analizlerde kullandığımız değişkenlerin (Bkz. Tablo 6) paket programda kullandığımız kısaltmaları yer almaktadır. Ayırma analizinde yer alan katsayıların ve bulunan diskriminant fonksiyonlarının anlamlılığının test edilmesinde Wilks' Lambda değeri kullanılmaktadır. Wilks' Lambda 0,0 ve 1,0 arasında değer alır. Tablo 11'de Wilks's Lambda değerlerin tamamı bu aralıkta yer almaktadır. Küçük lambda değerleri, analizde kullanılan değişkenlerin kümeler arası farklılıkları açıklamada etkili olduklarını, başka bir ifade ile küme merkezlerinin birbirlerinden ayrılmış olduklarını gösterir. Tablo 11'deki Wilks's Lambda değerleri; kişi başı brüt yurt-içi enerji tüketimi $(0,081)$,inşaat ve imalat sektöründen kaynaklanan kişi başı sera gazı emisyonu $(0,017)$, ulaştırma sektöründen kaynaklanan kişi başı sera gazı emisyonu $(0,038)$ gibi değişkenlerde en düşük değerlere sahiptir. Bu nedenle, bu değişkenlerin kümeler arası farklılıkları açıklamada daha etkili olduklarını söyleyebiliriz. Buna karşııı, göreli olarak daha büyük lambda değerlerine sahip olan kişi başı brüt yurt-içi nükleer 1sı tüketimi $(0,378)$, kişi başı brüt yurt-içi yenilenemeyen enerji tüketimi $(0,535)$, katı yakıtlarda enerji bağımlılığı $(0,693)$, enerji sektöründen kaynaklanan kişi başı sera gazı emisyonu $(0,542)$ ve endüstriyel üretimden kaynaklanan kişi başı sera gazı emisyonu $(0,589)$ değişkenlerinin, kümeler arası farklılıkları açıklamada daha az etkili oldukları söylenebilir. 


\section{Sonuç}

$\mathrm{Bu}$ makalede $\mathrm{AB}$ tarafından yayınlanan düşük karbon ekonomisi göstergeleri kullanılarak, $\mathrm{AB}$ üyesi ülkelerin ve Türkiye'nin, iklim değişikliğine dirençli düşük karbon ekonomisine geçiş performansları ortaya konmaya çalışılmıştır. AB'nin yayınladığı 23 iklim değişikliği göstergesi kullanılarak yapılan kümeleme analizi ve ayırma analizleri sonucunda, ele alınan 29 ülke benzerlikleri bakımından gruplandırılmıştır. İklim değişikliği göstergeleri açısından benzer performansa sahip olan ülkeler aynı kümede yer almıştır. Literatürde yer alan çalışmalarda ülkelerin iklim değişikliği karşısında gösterdikleri başarı, genellikle daha az sayıda göstergeyi kapsayan endekslerle ölçülmüştür.

Ampirik bulgularımız, ele aldığımız 29 ülkenin iklim değişikliği göstergeleri bakımından 10 farklı grupta toplanabileceğini göstermiştir. Dolayısıyla, $\mathrm{AB}$ ülkeleri ve Türkiye'nin iklime dirençli bir topluma geçişte 10 farklı gelişme düzeyi sergiledikleri gözlenmiştir. Bulgular, iklime dirençli bir ekonomiye geçişte çok vitesli Avrupa argümanının geçerli olduğunu ortaya koymuştur. İlk kümede Belçika, Avusturya ve Hollanda yer almaktadır. İkinci küme, ilk küme ile karşılaştırıldığında daha kalabalıktır. İkinci kümede İspanya, İtalya, Portekiz, Bulgaristan, Macaristan, Yunanistan, Hirvatistan, Letonya ve Litvanya yer almaktadır. Bu küme genellikle AB'nin Akdeniz ülkeleri ile AB'ye sonradan katılan ülkeleri kapsamaktadır. Üçüncü küme, ikinci küme gibi çok sayıda ülkeyi kapsamaktadır. Almanya, Slovenya, Polonya, Çek Cumhuriyeti, Fransa, Slovakya bu kümede yer alan ülkelerdir. Bu kümenin özelliği, AB’nin iki köklü üyesi olan Almanya ve Fransa'yı kapsamasıdır. Dördüncü küme üç üyeden (Romanya, İngiltere ve Danimarka) oluşurken, yedinci küme (Güney Kıbrıs ve Malta) ve dokuzuncu küme (Finlandiya, İsveç) ikişer üyeden oluşmuştur. Dört kümede sadece birer ülke yer almıştır. Başka bir ifade ile dört ülke (Lüksemburg, Türkiye, Estonya ve İrlanda) başka ülkelerle küme oluşturmamış, tek başlarına küme içinde yer almışlardır. Yaptığımız ayırma analizleri, Türkiye'nin yer aldığı kümenin diğer ülke gruplarından çok fazla ayrıştığını ortaya koymuştur. Bu bulgu, iklim değişikliği endeksi 2015 sonuçları ile uyumludur. Nitekim, 2015 yılı iklim değişikliği endeksinde Türkiye'nin bu konudaki performansının "çok zayıf” olduğu belirtilmiştir.

Analiz bulguları, AB’nin iklim değişikliği politikalarına ışık tutmalıdır. $A B$, tüm üyeler için standart hedefler belirlemek yerine, iklim değişikliği göstergeleri bakımından üye ülkelerin bulundukları farklı gelişme aşamalarına uygun hedefler belirlemeli ve uygulayacağı politikaları çeşitlendirmelidir. $\mathrm{AB}$ ülkeleri ile değerlendirildiğinde, iklim değişikliği göstergeleri bakımından en kötü durumda bulunan Türkiye’nin bu konuda daha duyarlı ve titiz davranması gerektiği ortadadır. 


\section{Kaynakça}

Atik, Hayriye. “Türkiye'de 6360 ve 6447 Sayılı Kanunlarla Kurulan Büyükşehirlerin Göreli kalkınma Düzeyleri”, TISK Akademi, Cilt 10, No.20, 2015, s.371-389.

Başoğlu, Aykut. "Küresel İklim Değişikliğinin Ekonomik Etkileri”, KTÜ Sosyal Bilimler Enstitüsü Dergisi, Sayı 7, 2014, s.175-196.

Biesbroek, G.Robbert et.al. "Europe Adapts to Climate Change: Comparing national Adaption Strategies", Global Environmental Change, No.20, 2010, s.440-450.

Birleşmiş Milletler, 1972, BMIDÇS, Madde 1(2).

Cline, William R. The Economics of Global Warming, Washington DC, Institute for International Economics, 1992.

Enerji ve Tabii Kaynaklar Bakanlığı, Türkiye Ulusal Yenilenebilir Enerji Eylem Planı, http://www.eie.gov.tr/ duyurular_haberler/document/Turkiye Ulusal_Yenilenebilir_Enerji_Eylem_Plani.PDF, (Erișim Tarihi 07 Ekim 2015).

European Commission. Energy Roadmap 2050, Luxembourg, European Union, 2012

European Union. Smarter, Greener More Inclusive: Indicators to Support The 2020 Strategy, Luxembourg, 2015.

Eurostat. Climate Change Statistics, http://ec.europa.eu/eurostat/statistics-explained/index.php/Europe 2020_indicators_-_climate_change_and_energy, (Erişim Tarihi 1 Nisan 2015).

Eurostat. Greenhouse Gas Emissions, http://ec.europa.eu/eurostat/tgm/table.do?tab=table\&init=1\&language= en\&pcode=t2020_30\&plugin=1, (Erişim Tarihi 09 Eylül 2015).

Eurostat. Share of renewable energy in gross final energy consumption, http://ec.europa.eu/eurostat/tgm/table.do? $\mathrm{tab}=$ table\&init $=1$ \&language $=$ en\&pcode $=\mathrm{t} 2020 \_31$ \&plugin $=1,($ Erişim Tarihi 09 Eylül 2015).

Fankhauser, Samuel. “The Social Costs of Greenhouse Gas Emissions: An Expected Value Approach”, Energy Journal, Cilt 15, No.2, 1994, s.157-184.

Fankhauser, Samuel. Valuing Climate Change: The Economics of the Greenhouse, London, Earth scan Publication Ltd., 1995.

German watch ve Climate Action Network Europe. The Climate Change Performance Index 2015,Brüksel, 2015.

Karakaya Etem ve Burcu Yılmaz. “AB’nde Enerji ve İklim Değişikliği Politikalarının Gelişimi”, Pınar Gedikkaya Bal ve Rana İzci Connelly (der.), Ekonomik Kriz ve Avrupa Birliği, İstanbul, Der Yayınevi, 2016.

Kok, Wim. Facing the Challenge: The Lisbon Strategy for Growth and Employment, Report From the High Level Group, 2004.

Kopuzlu, Haluk Kürşat. “Avrupa Birliği Üçüncü Enerji Paketi”, 3eElectrotech Dergisi, http://3eelectrotech.com. tr/arsiv/yazi/avrupa-birlidi-3-enerji-paketi, (Erişim Tarihi 4 Ekim 2016).

Nakip, Mahir. Pazarlama Araştırmaları: Teknikler ve SPSS Destekli Uygulamalar, Ankara, Seçkin Yayınevi, 2003.

Nian, Yang. "Low Carbon Economy Evaluation Index System and Development Evaluation of Hebei", Sixth International Conference on Business and Financial Engineering Conference, 2013.

Nordhaus, William D. "To Slow or Not to Slow: The Economics of The Greenhouse Effect", The Economic Journal, Cilt 101, No.407, 1991, s.920-937.

Öniş, Ziya ve Mustafa Kutlay. “Ekonomik Bütünleşme/ Siyasal Parçalanmışlık Paradoksu: Avro Krizi ve Avrupa Bütünleşmesinin Geleceği”, Uluslararası İlişkiler Dergisi, Cilt 9, Sayı 33, 2012, s.3-22.

Önsöz, Melih. "AB, 2030 İklim ve Enerji Paketi Üzerinde Anlaşmaya Vardı, Ekonomik Forum, 2014, s.64-68, http://haber.tobb.org.tr/ekonomikforum/2014/246/064_068.pdf, (Erişim Tarihi 1 Ekim 2016).

Özdamar, Kazım. Paket Programlar ile İstatistiksel Veri Analizi-2:Çok Değişkenli Analiz (SPSS, MİNİTAB), Eskişehir, Kaan Kitabevi, 2004.

PwC UK, www.pwc.co.uk, (Erişim Tarihi 27 Nisan 2015). 
Schelinhuber, Hans-Joachim. "Physical and Economic Consequences of Climate Change in Europe", Proceedings of the national Academy of Science, 15 Şubat 2011, http://www.pnas.org/content/108/7/2678.full, (Erişim Tarihi 26 Nisan 2016).

Tilford, Simon ve Philip Whyte. The Lisbon Scorecard X The Road to 2020. London, The Centre for European Reform, 2010.

Titus, James G. "The Cost of Climate Change to the United States", Shyamal K. Majumdar et.al. (der.), Global Climate Change: Implications, Challenges and Mitigation Measures, Easton, Pennsylvania Academy of Science, 1992.

Tompkins Emma L. et.al. "Observed Adaption to Climate Change: UK Evidence of Transition to a WellAdapting Society”, Global Environmental Change, Cilt 20, 2010, s.627-635.

Türkeş, Murat et.al. "Kyoto Protokolü Esneklik Mekanizmaları (Flexibility Mechanisms under the Kyoto Protocol)", Tesisat Dergisi, Cilt 52, s.84-100.

World Economic Forum. The Lisbon Review 2008:Measuring the Europe's Progress in Reform. Geneva, World Economic Forum, 2008.

Zhang, Zhong Xian. "China in Transition to A Low-Carbon Economy”, Energy Policy, No.38, 2010, s.6638-6653. 